\title{
Retrospective Evaluation of the Female Patients with Breast Cancer: Western Black Sea Region, Unicentered, Clinical Data of Oncology
}

\author{
Huseyin ENGIN ${ }^{1}$, Faruk SAYLIK ${ }^{2}$, Cemil BILIR ${ }^{1}$ \\ ' Bulent Ecevit University Faculty of Medicine, Department of Oncology, Zonguldak \\ 2 Bulent Ecevit University Faculty of Medicine, Department of Internal Medicine, Zonguldak, TURKEY
}

\begin{abstract}
ABSTRAC
Breast cancer is the most common female cancer in the world wide with $30 \%$ of all women cancer and second most common cause of cancer death in women. Oncology department of Bulent Ecevit University Faculty of Medicine is the only cancer center in western part of Black Sea region. We investigated retrospectively our data of women breast cancer between the period of 2000 and 2010 in this region. The mean age of the study population was $49.90 \pm 12$ years and mean follow-up time was $4 \pm 2$ years. The distribution of patients by the age, $25 \%$ or patients under 40 years old, $32 \%$ between the $40-50$ years old and $43 \%$ of them over the 50 years old. $92.6 \%$ of the patients were presented with a palpable mass. The most common type of breast cancer was invasive ductal carcinoma (IDC) in 312 patients (80\%). Prognosis of the study population; 309 patients (80\%) are surviving without any disease. Sixty-six patients (17\%) had progression, 7 of 390 patients $(1,8 \%)$ had local recurrence and 15 patients $(3.8 \%)$ died. While the breast cancer is one of the most commonly seen solid organ tumors in Black Sea region and, based on the literature, no significant differences were observed for prognostic factors, longer life expectancy of the patients with advanced stage disease may be attributed to higher number of patients with hormonal positivity and therapy adherence.
\end{abstract}

Keywords: Breast cancer, Woman, Prognosis, Survival

\section{ÖZET}

\section{Meme Kanserli Kadınların Retrospektif Analizi: Batı Karadeniz Bölgesi Tek Merkez Onkoloji Klinik Verileri}

Meme kanseri tüm dünyada kadınlardaki en sık kanser türü olup kadın kanserlerinin \%30'nu oluşturur ve kadınlarda kansere bağIı en sık ölüm nedenidir. Bulen Ecevit Üniversitesi Onkoloji Bölümü Batı Karadenizdeki tek kanser merkezidir. 2000 ila 2010 yllları arasında kadınlarda meme kanserini retrospektif olarak araştırdık. Çalışmamızdaki populasyonun ortalam yaşı $49.90 \pm 12$ 'di ve ortalama takip süresi $4 \pm 2$ yıldı.Hastaların yaşa göre dağııımında \%25'ini 40 yaş ve altı, \%32'sini 40-50 yaş arası oluşturmaktayken kalan \%43'de 50 yaş ve üzeri hastalar oluşturmaktaydı.En sık görülen kanser tipi 312 hastada saptanan invazif duktal karsinomdu (\%80). Hastaların prognozuna baktığımızda; 309 hasta(\%80) hastalıksız sağkalımda, 66 hastada (\%17) progresyon, 7 hastada $(\% 1,8)$ local nüks ve 15 hastada $(\% 3,8)$ ölüm görüldü. Meme kanseri Batı Karadeniz bölgesindeki kadınlarda en sık görülen solid organ tümörlerden olup prognostik faktörler ve ileri evre hastalığı olanlardada uzun yaşam beklentisi açısından anlamlı bir fark saptanmadı. Hormonal pozitiflik ve tedavi uyumu bu duruma en önemli katkıyı sağlamaktaydı.

Anahtar Kelimeler: Meme kanseri, Kadın, Prognoz, Sağkalım 


\section{INTRODUCTION}

In the epidemiological studies conducted, breast cancer accounted for $28-32 \%$ of all the cancers and for $17.6 \%$ of the cancer-related deaths among women worldwide. ${ }^{1,2}$ One out of 9 women have the risk for the development of invasive breast cancer in their life time. ${ }^{3}$

In our country, based on the data published by Ministry of Health, in 2005, a total of 24815 patients were diagnosed with cancer and the incidence of cancer was calculated as 173.85 in 100,000. Of all cases of cancer, 4466 were the patients with breast cancer, which was the most common type of cancer with a percentage of $35.47 \% .{ }^{4}$ Furthermore, in an epidemiological study performed by Fidaner et al. in the region of Izmir, the incidence of breast cancer was found to be 23.4/100.000 in this region. ${ }^{5}$

Lymph node status and the size of the tumor are the most important prognostic factors in terms of the recurrence of breast cancer and overall survival. ${ }^{6,7}$ Other prognostic factors include the grade of the tumor, lymphatic and vascular invasion, Ki-67 proliferation marker, the age of the patient at the time of diagnosis, estrogen and progesteron receptor status, Human Epidermal Growth Factor Receptor 2 (HER-2/neu) status, urokinase plasminogen activator (uPA) and plasminogen activator inhibitor-1 (PAI-1) genetic profile. ${ }^{8}$

In this study, we aimed to investigate the statistical information, early diagnosis and prognostic factors, by retrospectively evaluating the clinical and laboratory data of the patients with breast cancer, who were admitted to and then followed up in Bulent Ecevit University, Clinical Practice and Research Hospital, Medical Oncology outpatient clinic between 2000 and 2010.

\section{MATERIAL AND METHODS}

In this study, the clinical and laboratory data of the patients with breast cancer, who were admitted to and followed up in Bulent Ecevit University, Practice and Research Hospital, Medical Oncology outpatient clinic between 2000 and 2010, were retrospectively evaluated. During that period, among 470 patients, records of 390 patients which were available were retrospectively evaluated. The following information were recorded for each of the subjects: age, complaints at the time of presentation, familial history, tumor localization, the type of surgery performed, pathological TNM classification, histopathological type of the tumor, the grade of the tumor, estrogen, progesteron and cerb2 receptors status, the number of the lymph nodes involved, adjuvant therapies received, status of metastasis, the sites of metastasis, metastasis at the time of diagnosis, and the rates of death or disease-free survival. Based on this information, each patient was staged using TNM staging system based on American Joint Committee clinical staging system 2003 (AJCC).

Duration of follow-up was considered as the time from the diagnosis to the end of the study. A disease-free survivor group was formed by excluding the patients with progression and death from overall cases. The patients, who were controlled at least 3 months ago, were contacted via telephone and their data were updated by February 2010. Finally, the actual statuses of disease-free survival, progression or exitus of the patients were demonstrated.

Statistical Analysis: In the analysis of the study, SPSS 18.0 software was used. Descriptive statistics were reported as the mean or median with standard deviation. Unpaired $t$ tests were performed for data with normal distribution. For parameters that did not show normal distribution, the non-parametric Mann Whitney U test was used to compare. Between-group analyses were performed using one-way ANOVA or chi-squrae. Kaplan-Meier and Cox regression analysis were used in the analysis of time to event variable and the $95 \%$ confidence interval (CI) for the median time to event was computed. The 95\% CI was selected, and p value of 0.05 was set for statistically significance. Correlations were studied using Spearman correlation coefficient.

\section{RESULTS}

The study was performed on 390 subjects who were admitted to, treated and followed up at Bulent Ecevit University, Practice and Research Hospital, Medical Oncology Outpatient Clinic between 22.10.2000 - 01.01.2010. The age distribution of these patients was as follows, $24.7 \%$ were $\leq 40$ years-old, $31.5 \%$ were between $40-50$ years-old and $43.8 \%$ were $\geq 50$ years-old. Mean age of the patients was $49.90 \pm 12$ years. The total person time of 


\begin{tabular}{|c|c|c|}
\hline & Number & $\%$ \\
\hline IDC & 312 & 80.0 \\
\hline ILC & 26 & 6.7 \\
\hline IDC+ILC & 12 & 3.1 \\
\hline Mucinous & 10 & 2.6 \\
\hline Medullar & 8 & 2.1 \\
\hline DCIS & 7 & 1.8 \\
\hline Tubular & 4 & 1.0 \\
\hline Ppillar & 3 & 0.8 \\
\hline Mesenchymal Tumor & 3 & 0.8 \\
\hline LCIS & 2 & 0.5 \\
\hline IDC+DCIS & 2 & 0.5 \\
\hline IDC+DCIS+LCIS & 1 & 0.3 \\
\hline Total & 390 & 100.0 \\
\hline
\end{tabular}

follow-up was 1703 years. The median follow up time was 5 (1-10) years. The most common complaint at the time of presentation was a palpable mass, with a rate of $92.6 \%$. Of the patients, 3 $(0.8 \%)$ had nipple discharge, $12(3.1 \%)$ had pain + nipple discharge, $4(1 \%)$ had redness, $4(1 \%)$ had only pain and 6 of the patients $(1.5 \%)$ were detected during the examination. When the tumor localization was evaluated in the cases, 200 patients $(51.3 \%)$ had a tumor localized in the right breast, 183 patients $(46.9 \%)$ had a tumor localized in the left breast, and 7 patients (1.8\%) had a tumor localized in both breasts. The pathologic subtypes of breast cancer were presented in the Table 1 .

There is a significant correlation between the metastatic lymph node number and overall survival (Pearson correlation coefficient $=0.65 ; \mathrm{p}=0.037$ ) . There is a negative correlation with cerbB2 status and overall survivals (OS) $(\mathrm{p}=0.0001)$. According to the immunohistochemical analysis, CerbB2 negative, one and two positive values accepted negative hormonal status because these patients didn't recieved trastuzumab treatment. CerbB2 $3+$ and $4+$ accepted positive and treated with trastuzumab. There is no statically significant differences of OS

\begin{tabular}{|c|c|c|}
\hline & Patients & $\begin{array}{l}\text { Cummulative } 5 \\
\text { years survivall (\%) }\end{array}$ \\
\hline ER negative & 101 & 89 \\
\hline $\mathrm{ER}+$ & 102 & 96 \\
\hline $\mathrm{ER}++$ & 79 & 97 \\
\hline ER+++ & 75 & 95 \\
\hline ER++++ & 33 & 100 \\
\hline PR negative & 120 & 92 \\
\hline PR positive & 270 & 97 \\
\hline CerbB2 negative & 335 & 95 \\
\hline CerbB2 Positive & 55 & 89 \\
\hline
\end{tabular}

between the positive/negative cebrB2 status ( $\mathrm{p}=$ $0.19)$. When the survival rates were evaluated according to the stages, 5 years survivall rate was $98 \%$ and 10 years survivall rate was $94 \%$. According the ER, PR and CerbB2 status, relationships between the each categorical variable with OS measured by chi-square test. For ER status there was no significant difference between the quantity of ER positivity with OS $(\mathrm{p}=0.052)$ and also there was significant difference between the PR negative and PR positive patients for $\mathrm{OS}(\mathrm{p}=0.21)$. CerbB2 status did not effect the survival $(\mathrm{p}=0.19)$ and these parameters presented in the Table 2. Of 101 patients $(25.9 \%)$ that were ER-negative, 6 died. Of 120 patients $(30.8 \%)$ that were PR-negative, 5 (33.3\%) died.

At the time of diagnosis of breast cancer, menopause status was presented in Table 3. Of the cases investigated, 334 patients (85.6\%) underwent modified radical mastectomy (MRM) as the surgical therapy. Two patients $(0.5 \%)$ underwent radical mastectomy (RM), 20 patients (5.1\%) underwent lumpectomy + ad and $32(8.2 \%)$ underwent simple mastectomy. Two patients $(0.5 \%)$ were considered as inoperative. 


\begin{tabular}{|lll|}
\hline $\begin{array}{l}\text { Table 3. Menopausal status at the time of diagnosis of } \\
\text { breast cancer }\end{array}$ & Number & $\%$ \\
\hline & 156 & 40 \\
\hline Pre-menopausal & 60 & 15.4 \\
Peri-menopausal & 174 & 44.6 \\
Post-menopausal & 390 & 100.0 \\
Total & & \\
\hline
\end{tabular}

Stage is one of the most important prognostic factor. With advanced stage, the rate of survival decreases. 5 years OS was $97 \%$ in the early stage but $74 \%$ in the stage $4(\mathrm{p}=0.0001)$ also had shown in Figure 1.

Of 390 patients examined, 7 (1.8\%) had local recurrence, 81 (20.8\%) had metastasis, 15 (3.8\%) died. When the sites of metastasis were evaluated, bone was the most common site of metastasis with 33 patients $(40.7 \%)$. When, together with bone metastasis, liver, lung and brain metastasis were calculated, 54 patients $(66.5 \%)$ showed bone metastasis. This was respectively followed by liver metastasis in 8 patients (9.9\%), lung metastasis in 8 patients (9.9\%), bone + liver metastasis in 7 patients $(8.6 \%)$, bone + brain metastasis in 7 patients $(8.6 \%)$, skin metastasis in 6 patients $(7.4 \%)$, and bone + liver + lung metastasis in 4 patients (4.9\%).

Three hundred fourty-one patients $(87.4 \%)$ received adjuvant chemotherapy. Forty-nine patients $(12.6 \%)$ could not receive chemotherapy. When the chemotherapy regimens were evaluated, the most commonly administered regimen was AC (doxorubicine + cyclophosphamide) with 185 patients $(47.4 \%)$ and their survival rate was $95.6 \%$. Second most commonly administered chemotherapy regimen was FEC (5-fluorouracyl + epirubicine + cyclophosphamide) which was given to 75 patients $(19.2 \%)$ and the survival rate of these patients was 98.6\%. Third most commonly administered chemotherapy regimen was CAF (5 fluorouracyl + doxorubicine + cyclophosphamide) that was given to 57 patients $(14.5 \%)$ and the survival rate of these patients was $94.7 \%$.

It was found that, of the patients enrolled to the study, 309 (79.2\%) were disease-free survivors, 66 $(17 \%)$ showed progression and $15(3.8 \%)$ died.

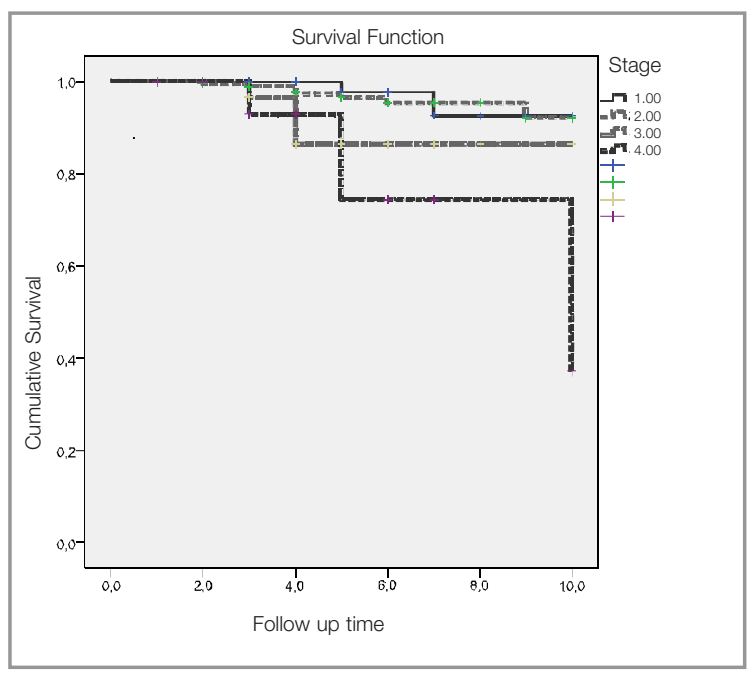

Figure 1. Overall Survival for Stage of Breast cancer

\section{DISCUSSION}

Based on the data from our clinic, which is the only oncology center in the Black Sea region, we concluded that age is an important independent risk factor for breast cancer. In our study, we found that "palpable mass" was the first detected finding in the breast cancer, and in the presence of perineural invasion, the involvement of lymph node was higher, and with the increasing number of axillar lymph nodes involved the survival rates remained stable and in our region, ER-positive and PR-positive breast cancers were more common compared to the data in the literature (respectively, $74.2 \%$ and $69.2 \%$ ). We found that $87.4 \%$ of our patients received adjuvant chemotherapy and that disease-free survival rate of our patients was $79.2 \%$.

The idea that the breast cancer is not only a disease but it should be considered as a combination of different pathological processes, with different courses and prognosis is increasingly accepted. Longterm survival is not primarily and solely determined with early diagnosis, but is also based on the biological behavior and the malignancy potential of the tumor. ${ }^{9}$

The breast cancer incidence shows a marked increase with advanced age. When we examine the age distribution of 390 patients enrolled to our study, we observed that mean age was $49.90 \pm 12$ years and $75.3 \%$ of the patients were $\geq 40$ years-old. This finding overlaps with the reality that the age is an im- 
portant independent risk factor for the breast cancer. In a study performed on 1381 subjects, the number of the patient with breast cancer in the 4070 years of age group was $67.5 \%$ of all the subjects. ${ }^{10}$

When we examine the complaints of our patients during admission, we see that the most common reason of presentation is "palpable mass" (92.6\%). In the literature, it is highlighted that $70 \%$ of the women with breast cancer presents with a mass in the breast as the first finding..$^{11,12}$

Involvement of axillar lymph nodes is an important prognostic factor for the breast cancer. The status of the axillar lymph nodes leads better selection of the patients that require adjuvant chemotherapy and local radiotherapy. In many clinical studies, although the patients were grouped as node (-), 1 -3 nodes $(+)$ and $>4$ nodes $(+)$, a direct proportion was determined between the number of the nodes involved and the clinical course. ${ }^{13}$ In the study conducted by Nemoto et al. ${ }^{14}$, it was found that while the axillar involvement increases, the survival rate decreases. In the study performed by Martin et al. ${ }^{15}$, it was found that 8 -year survival rate was $87.5 \%$ in the patients with no axillar involvement, $85.5 \%$ in the patients with 1 node involved and $49.1 \%$ in the patients with $\geq 2$ lymph nodes involved, and that the impact of the axillar involvement on the survival rate was statistically significant. In our study, we also found significant negative correlation between the lymph node invasian with OS.

The stage of the tumor is an important indicator of the survival, alone and/or together with other prognostic factors. In our study, the most commonly seen stage of tumor was Stage 2A, with a rate of $40.3 \%$. This resulted from the fact that the patients presented to the doctor in the late stage and when they were symptomatic. When we compared our data with other data of the literature, the survival rates of our patients with Stage 1 and Stage 2 were consistent with others, but, the survival rates of our patients with Stage 3 and Stage 4 were higher in our population. Given that our median duration of follow-up was 5 years, our results corresponded to the results obtained in the literature. One reason of these high values could be the hormonal status as ER and PR are independent prognostic factors in the breast cancer. ER and PR positivity indicates the response to hormonal therapy and a better prognosis. On average $55-65 \%$ of the cases with primary breast cancer are ER-positive. Approximately 45$60 \%$ of the cases with breast cancer are PR-positive. In our study, ER and PR positivity was found to be respectively $74.2 \%$ and $69.2 \%$ and this could explain the contribution to the survival.

Although it is generally highlighted that there is a relation between the decrease of survival and CerbB2 positivity, it should be noted that the results about the survival are conflicting. Paik et al..$^{16}$ found a correlation between Cerb-B2 positivity and the decreasing survival only in the patients that have a tumor with a good nuclear grade. Again, Slamon et al. ${ }^{17}$ showed in their multivariate analysis that there was a significant independent correlation between Cerb-B2 positivity and the recurrence and poor survival. There are also some studies that indicate the relation between the decreased survival and CerbB2 positivity in the cases with Cerb-B2 positivity in their axillar area. ${ }^{18}$ In our study, when we examine the survival rates according to stages, we see that, with advanced stage, the rate of death increases and the survival rate decreases. We also found a negative correlation between the cerbB2 status and OS but there is no statically significant.

During the last few years, observed decrease in the mortality of breast cancer was also due to the development of adjuvant therapies. Current guidelines recommend adjuvant chemotherapy following the systemic surgery. In a study, it was seen that polychemotherapy reduced post-operative recurrences and deaths in the patients below 70 years-old and with tamoxifen similar results achieved in all age groups. ${ }^{19}$ Therefore, current guidelines recommend adjuvant chemotherapy for all patients, regardless of the age. We found that, of the patients that we screened, $87.4 \%$ had received adjuvant chemotherapy. We determined that the most commonly administered chemotherapy regimens were AC (doxorubicine + cyclophosphamide) with a rate of $47.4 \%$, FEC (5-fluorouracyl + epirubicine + cyclophosphamide) with a rate of $19.2 \%$ and CAF (5 fluorouracyl + doxorubicine + cyclophosphamide) with a rate of $14.5 \%$. For all of the 3 chemotherapy regimens, mean survival rate was $95 \%$.

Radiotherapy has an important role in the adjuvant therapy administered for early breast cancer. In our 
study, we found that $71 \%$ of the patients received radiotherapy. For the radiotherapy given after the surgical therapy for breast cancer, the effect on survival rate and the contribution to the prevention of the local and regional recurrences are clearly established. ${ }^{20}$

The histopathological classification accepted today is performed according to tumor characteristics and the source cells. Ninety percent of the breast tumors are consisted of invasive ductal carcinoma (IDC) + invasive lobular carcinoma (ILC). ${ }^{21}$ Ductal breast cancers are $80 \%$ of all breast cancers. In our study, IDC + ILC were found to be $90.6 \%$.

As the site of metastasis, we found that the most common metastasis were bone metastasis with a rate of $66.5 \%$. This was respectively followed by liver, lungs and brain. In a study performed, consistent with the results of our study, the most common site of metastasis was bone with a rate of $63.2 \%{ }^{22}$

The survival time of the untreated patients at a same clinical stage of the disease varies between several months to several decades. ${ }^{23}$ At the end of our study, when we examined the ultimate condition of the patients, we found that $79.2 \%$ were disease-free survivors, $17 \%$ had progression and $3.8 \%$ died.

Consequently, while the breast cancer is one of the most commonly seen solid organ tumors in Black Sea region and, based on the literature, no significant differences were observed for prognostic factors, longer life expectancy of the patients with advanced stage disease may be attributed to higher number of patients with hormonal positivity and therapy adherence.

\section{REFERENCES}

1. Ferlay J, Autier P, Boniol M, Heanue M, et al. Estimates of the Cancer incidence and mortality in Europe in 2006. Ann Oncol 18: 581-92, 2006.

2. Jemal A, Siegel R, Ward E, Murray $T$, et al. Cancer Statistics, CA Cancer J Clin 57: 43-66, 2007.

3. Fauci AS, Braunwald E, Kasper DL. Kasper Breast Cancer Harrison's Principles of Internal Mehdicine 17th Ed. New York, McGraw-Hill Companies, 2008: 563-570.
4. Mollahaliloğlu S, Kosdak M, Eryilmaz Z. The Ministry of Health of Turkey, Health Statistics Yearbook. Hıfzıssınha Mektebi Müdürlüğü, Refi k Saydam Hıfzıssınha Merkezi Başkanlığı, Sağlık Bakanlığı, Ankara 2008.

5. Fidaner C, Eser SY, Parkin DM. Incidence in Izmir in 1993-1994: first results from Izmir Cancer Registry. Eur J Cancer 37: 83-92, 2001.

6. Rosen PP, Groshen S, Saigo PE, Kinne DW, et al. Pathological prognostics factors in stage I (T1NOMO) and stage II (T1N1MO) breast carcinoma: a study of 644 patients with median follow-up of 18 years. J Clin Oncol 7: 1239-12351, 1989.

7. Smart CR, Byrne C, Smith RA, Garfinkel L, et al. Twenty-year follow-up of the breast cancers diagnosed during the Breast Cancer Detection Demonstration Project. CA Cancer J Clin 47: 134-149, 1997.

8. Cianfrocca M, Goldstein LJ. Prognostic and predictive factors in early-stage breast cancer. Review. The Oncologist 9: 606-616, 2004.

9. Brinkley D, Habittle J. Long-term survival of woman with breast cancer. Lancet 1: 1109-18, 1984.

10. Donegan WL, Spratt JS. Cancer of the breast, 4 th ed. Br J Surg 82:1292, 1995.

11. Greenall MJ, Wood WC. Cancer of the breast. In: Oxford Textbook of Surgery (2nd Edition). Eds. P.J. Morris and W. C. Wood. Oxford University Press, United Kingdom 2000: 1191.

12. McCready T, Littlewood D, Jenkinson J. Breast selfexamination and breast awareness: a literature review. J Clin Nurs 14: 570-578, 2005.

13. Fisher B, Bauer M, Wickherman DL. Relation of number positive axillary lymph nodes to the prognosis of patients with primary breast cancer: an NSABP update. Cancer 52: 1551-1558, 1983.

14. Nemoto T, Vana J, Bedwani RN. Management and survival of female breast cancer. Cancer 45: 29172924, 1980.

15. Martin JK, van Heerden JA, Taylor WF. Is modified radical mastectomy really equivalent to radical mastectomy in treatment of carcinoma of the breast. Cancer 57: 510-518, 1986.

16. Paik S, Bryant J, Park C, Fisher B, et al. ErbB-2 and response to doxorubicin in patients with axillary lymph node-positive, hormone receptor-negative breast cancer. J Natl Cancer Inst 90: 1361-1370,1998.

17. Slamon DJ, Godolphin W, Jones LA, Holt JA, et al. Studies of the HER-2/neu proto-oncogene in human breast and ovarian cancer. Science 244: 707-712, 1989.

18. Skrabanek P. False premises and false promises of breast cancer screening. Lancet 2: 316-320, 1985. 
19. Early Breast cancer Trialists' Collabirative Group. Effects of chemotherapy and hormonal therapy for early breast cancer on recurrence and 15-year survival: an overview of the randomised trials. Lancet 365: 1687 1717, 2005.

20. Perez AC, Garcia MD, Kuske RR, Levitt SH. Breast in: Perez AC, Brady LW, eds. Principles and practice of radiation oncology. Philadelphia, Lippincott company, 1992: 877- 947.

21. AJCC cancer staging handbook. In: Grene F, Page D, Fleming I, Fritz A, Balch C, editors. PartVII- Breast. 6th ed. Chicago (IL): Springer-Verlag, pp: 257-81, 2002.

22. Selim Killç, Sabahat Tezcan, Şeref Kömürcü. GATA'da takip edilen meme kanserli hastaların demografik özellikleri. Gülhane Tıp Dergisi 45:189-195, 2003.

23. Bloom H, Richardson W, Harrier E. Natural history of untreated breast cancer. BMJ 213: 1805-933, 1962.

\section{Correspondence}

Dr. Cemil BiLiR

Sultan Orhan Mahallesi

1145 Sokak No: 14

Gebze, KOCAELI / TURKEY

Tel: (0.372) 2612880

Fax: (0372) 2610000

e-mail: cebilir@yahoo.com 